\title{
Fat Digestion in the Stomach: Stability of Lingual Lipase in the Gastric Environment
}

\author{
CAROL S. FINK, PAUL HAMOSH, AND MARGIT HAMOSH(71) \\ Department of Pediatrics and Department of Physiology and Biophysics, Georgetown University Medical Center, \\ Washington, D.C., USA
}

\begin{abstract}
Summary
Digestion of dietary fat starts in the stomach, where lingual lipase hydrolyzes triglycerides to free fatty acids and partial glycerides at pH 3.0-6.0. Lingual lipase is secreted continuously from lingual serous glands and accumulates in the stomach between meals, when gastric $\mathrm{pH}$ is $<3.0$. We have, therefore, examined the resistance of lingual lipase to low pH and its possible protection by dietary components present in the stomach contents. Partially purified rat lingual lipase (7-15 $\mu \mathrm{g}$ enzyme protein) was preincubated at $37^{\circ} \mathrm{C}$ for $10-60 \mathrm{~min}$ at $\mathrm{pH} 1.0-6.0$ before incubation for assay of lipolytic activity, hydrolysis of tri$\left[{ }^{3} \mathrm{H}\right]$ olein at $\mathrm{pH}$ 5.4. The data show that partially purified rat lingual lipase preparations are stable at $37^{\circ} \mathrm{C}$ in the $\mathrm{pH}$ range of 2.5-6.0. Enzyme activity, however, is rapidly and irreversibly lost during preincubation at $\mathrm{pH}$ 1.0-2.4 for 10-30 min. Protein (gelatin $1 \%$ or albumin $1 \%$ or $2.5 \%$ ) cannot prevent the inactivation of lingual lipase at low $\mathrm{pH}$. The large molecular species (molecular weight $\mathbf{7 0 0 , 0 0 0}$ ) of lingual lipase (thought to be an aggregate of enzyme with lipids) is slightly more resistant to inactivation than the 46,000 dalton preparation, suggesting that lipids might protect the enzyme from inactivation. Indeed, about $60 \%$ of the initial lipase activity is preserved during incubation at pH 2.0 in the presence of $50 \mathrm{mM}$ lecithin or $10 \mathrm{mM}$ triolein. The data indicate that triglycerides which are hydrolyzed by this enzyme as well as phospholipids that are not hydrolyzed can prevent the inactivation of the enzyme. Lingual lipase is resistant to peptic digestion, even at high pepsin concentrations. Because of the special importance of lingual lipase in neonatal fat digestion, we compared the stability of the lipase in gastric aspirates of newborn infants to that of rat lingual lipase. The lipase in human gastric aspirates is more resistant to inactivation than the rat enzyme. There are however individual variations in enzyme stability: from preservation of $100 \%$ of original activity to the loss of $80 \%$ of activity during incubation for $30 \mathrm{~min}$ at $\mathrm{pH} 1.6$. The data suggest that substances within the newborn infant's stomach stabilize the enzyme at low $\mathrm{pH}$. We suggest that the extensive intragastric hydrolysis of dietary fat (in formula or breast milk) is related to the stability of the lipase in the stomach of newborn infants.
\end{abstract}

\section{Abbreviations}

BSA, bovine serum albumin

FFA, free fatty acids

Digestion of dietary fat by lingual lipase is initiated in the stomach of the newborn $(4,28,29,40,63)$ and the adult $(10$, $26,28,51)$. Intragastric lipolysis results in the hydrolysis of $10-$ $30 \%$ of dietary fat to partial glycerides and FFA $(4,26,28,29$, $40,57,63)$. The products of intragastric lipolysis are amphiphilic substances (62) that facilitate fat emulsification (26) and enhance the intestinal hydrolysis of fat by pancreatic lipase (6). Recent studies show that the site of action of lingual lipase, an enzyme with optimal activity at $\mathrm{pH} 3.0-6.0$, is not limited to the stomach, but continues in the duodenum $(1,12)$, especially in conditions of physiologic $(9,10,37,47,69)$ and pathologic $(46,53,55,59)$ pancreatic insufficiency, characterized by low duodenal $\mathrm{pH}(12-$ $14,19)$. In these cases, the enzyme is probably responsible for the digestion and absorption of as much as $70 \%$ of dietary fat $(55,59)$.

Lingual lipase is secreted from von Ebner glands (67) located at the proximal site of the tongue beneath the circumvallate papillae $(24,28)$. Enzyme preparations from the supernatant $(100,000 \mathrm{~g})$ fraction of lingual serous gland homogenates have a molecular weight $>500,000$ daltons ( 25 ). Further purification by acetone extraction at low temperature $\left(-20^{\circ} \mathrm{C}\right)$ converts the enzyme to a low molecular form of 46,000 daltons (25). The latter molecular weight is identical to that of the lipase purified from gastric juice of newborn $(27)$ or adult humans $(8,65)$. The data suggest that the high molecular weight species results from aggregates of enzyme and cell membrane lipids during the process of tissue homogenization.

There is good evidence that lingual lipase is secreted continuously and accumulates in the stomach between meals $(1,26)$. Because the stomach $\mathrm{pH}$ decreases from postprandial levels of $4.5-6.0$ to $2.0-2.5$ between meals (32), we have investigated the effect of low $\mathrm{pH}$ on the activity of the high and low molecular weight forms of lingual lipase in order to assess whether the enzyme will remain active after exposure to low $\mathrm{pH}$.

\section{MATERIALS AND METHODS}

Animals. Adult male Sprague-Dawley rats, weighing approximately $250 \mathrm{~g}$ and maintained on Purina Laboratory Chow and water ad libitum, were used in these studies. The animals were anesthetized by IP injection of $50 \mathrm{mg} / \mathrm{kg}$ of sodium pentobarbital (Abbott Laboratories, North Chicago, IL), exsanguinated, and the tongues were removed and placed on ice.

Tissue preparation. The proximal area of the tongue was sliced to expose the lingual serous glands. The entire area beneath the circumvallate papilla was carefully dissected to remove the serous glands free from contamination by muscle. The tissue was homogenized in ice cold $0.9 \% \mathrm{NaCl}$ and centrifuged at $100,000 \mathrm{~g}$ at $4^{\circ} \mathrm{C}$ for $60 \mathrm{~min}$. Part of the supernatant was frozen at $-70^{\circ} \mathrm{C}$ for later use and the rest was extracted with acetone at $-20^{\circ} \mathrm{C}$ as described previously (25). Protein concentrations were determined by the method of Lowry et al. (43) using BSA (Fraction $\mathrm{V}$, Miles Laboratories, Inc., Elkhart, IN) as standard. Seven to $15 \mu \mathrm{g}$ of enzyme protein were used for the assay of lipolytic activity.

For the experiments described in this study, we used two batches of lingual lipase preparation. For each batch of lingual lipase (low and high molecular weight enzymes) we used lingual serous glands pooled from $10-15$ rats. 
Collection of gastric aspirates from newborn infants. Gastric aspirates were obtained from term infants delivered at Columbia Hospital for Women, Washington, D.C., as part of routine neonatal care. The specimens were frozen immediately and stored at $-70^{\circ} \mathrm{C}$ until analysis. Lipase activity is stable at $-70^{\circ} \mathrm{C}$ for years (27). The protocol was approved by the Institutional Review Board, and informed consent was obtained.

Determination of lipase activity. Lipolytic activity in preparations of rat lingual lipase or in specimens of gastric aspirates of newborn infants was measured with long chain triglyceride (triolein) as substrate. A stable triglyceride emulsion was prepared by mixing $200 \mu \mathrm{mol}$ of triolein (Sigma Chemical Company, St. Louis, MO) with tri-[9, $\left.10 \mathrm{n}^{3} \mathrm{H}\right]$ oleate (Amersham, TRA-191, Arlington Heights, IL) and $15 \mu \mathrm{mol}$ of phosphatidylcholine in chloroform. After evaporating the solvent, $3.3 \mathrm{ml}$ of anhydrous glycerol (Baker Chemical Corp, Phillipsburg, NJ) was added and the mixture was sonicated in a Polytron PCU-2-110 (Brinkman Instruments, Westbury, NY) at setting 7 for two periods of 1 min each. The emulsion was stored at room temperature and was stable for $3 \mathrm{mo}$. The triglyceride concentration of the substrate emulsion was quantitated by the hydroxamic acid method of Rapport and Alonzo (52).

Lipase assay system. The assay system contained in a final volume of $200 \mu \mathrm{l}: 1 \mu \mathrm{mol}$ triolein (specific activity, $400,000 \mathrm{dpm} /$ $\mu \mathrm{mol}) ; 10 \mu \mathrm{mol}$ of sodium citrate- $\mathrm{Na}_{2} \mathrm{HPO}_{4}$ buffer, $\mathrm{pH} 5.4 ; 7 \mathrm{mg}$ bovine serum albumin and enzyme, rat lingual lipase preparation or human gastric aspirate (7-15 $\mu \mathrm{g}$ protein). Incubation was for $30 \mathrm{~min}$ at $37^{\circ} \mathrm{C}$ in a Dubnoff shaking bath. The reaction was stopped by the addition of $3.25 \mathrm{ml}$ of a mixture of methanol:chloroform:heptane $(1.41: 1.25: 1.00, \mathrm{v} / \mathrm{v} / \mathrm{v})$. The FFA produced were separated from the glycerides (partial glycerides produced during the incubation and the unhydrolyzed triglyceride substrate) by the addition of $1.05 \mathrm{ml}$ of potassium carbonate buffer, $0.05 \mathrm{M}, \mathrm{pH} 10.0$ (5). Aliquots $(0.5 \mathrm{ml}$ each) of the aqueous phase were transferred to $5.0 \mathrm{ml}$ of Ready-Solv (Beckman Comp. Fullerton, CA) and the radioactivity measured in a Beckman Scintillation Counter (model LS 7500, Beckman Instruments, Inc., Fullerton, CA) using internal standards for quench correction. Of the total amount of FFA, $75-80 \%$ was present in the alkaline upper aqueous phase. The effect of variable conditions during enzyme preincubation studies, such as variations in $\mathrm{pH}$ from 1.0-6.0, addition of lecithin (5-50 mM), proteins (BSA or gelatin) or pepsin, on the partition of FFA between the nonaqueous and aqueous phases was tested by determining the partition coefficient of $\left[{ }^{3} \mathrm{H}\right]$ oleic acid in the two phases. The partition of FFA to the aqueous phase was not affected by any of the preincubation conditions tested, except for lecithin. In the latter case, appropriate controls were run with each experiment.

Analysis of reaction products formed during in vitro or in vivo hydrolysis of triglycerides. In these experiments, gastric aspirates were obtained at timed intervals after feeding. The lipids were extracted with chloroform:methanol $(2: 1)(15)$ and the glycerides and FFA were separated by column chromatography (28); the glycerides were quantitated by analysis of ester bonds (52) and the FFA by microtitration (11). For in vitro experiments, the reaction was stopped by the addition of $5 \mathrm{ml}$ of chloroform:methanol (2:1). The labeled reaction products (partial glycerides and FFA) and the unhydrolyzed triglyceride substrate were separated by thin layer chromatography and quantitated by liquid scintillation counting (28).

Preincubation studies. For stability studies, aliquots of rat lingual lipase preparations $(100,000 \mathrm{~g}$ supernatants of lingual serous gland homogenates, which are high molecular weight species, and acetone extracts of this preparation, which are low molecular weight enzyme species), were incubated for $0,10,30$, and $60 \mathrm{~min}$ at $37^{\circ} \mathrm{C}$ at $\mathrm{pH} 1.0-6.0$. The buffers for the various $\mathrm{pH}$ ranges were glycine- $\mathrm{HCl}(12.5 \mathrm{mM}), \mathrm{pH} 1.0-2.0$; and citratephosphate buffer $(12.5 \mathrm{mM}), \mathrm{pH} 2.5-6.0$. At the end of the preincubation period, the $\mathrm{pH}$ was rapidly adjusted to 5.4 and aliquots were incubated in the lipase assay system described above.

\section{RESULTS}

Comparison of hydrolysis of fat in the stomach with in vitro hydrolysis of triolein by rat lingual lipase and human gastric aspirates. The extent of hydrolysis and the nature of the reaction products formed during in vivo lipolysis or during incubation of lingual lipase with triolein substrate are very similar, indicating that fat hydrolysis in the stomach is catalyzed by lingual lipase (Table 1). The data presented in Table 1 suggest, therefore, that the stability of lingual lipase in the gastric milieu could be investigated in vitro by simulating the conditions in the stomach between and after meals.

Because lingual lipase is secreted continuously from lingual glands $(1,26)$ and probably accumulates in the stomach between meals (1), we investigated the effect of low $\mathrm{pH}$ on lipase activity. In the experiments described below, rat lingual lipase preparations were first preincubated without substrate under various experimental conditions, followed by $\mathrm{pH}$ adjustment of 5.4 (optimum for lingual lipase activity), addition of labeled triolein substrate, and measurement of lipase activity. We used two preparations of rat lingual lipase: a large molecular weight species, which is probably an aggregate of the enzyme with polar lipids, and a low molecular weight species, prepared by delipidation of the former with acetone. The smaller enzyme species is identical in molecular weight (44-48,000 daltons) to the lipase in gastric aspirates of newborn infants (27) and healthy adults $(8,65)$. We showed previously that the two enzyme preparations (large and small) have the same level of activity (25); however, we did not know whether they differed in stability.

Effect of preincubation in the $\mathrm{pH}$ range of 1.5-6.0 on the activity of lingual lipase. A comparison between the stability of the two forms of lingual lipase to low $\mathrm{pH}$ is given in Figures 1 and 2 . Both enzyme preparations are stable in the pH range of 2.5-6.0: the large molecular weight species retaining $90-95 \%$ of the original activity (Fig. 1), and the low molecular weight species retaining $75-85 \%$ of the initial activity (Fig. 2) after preincubation for $10-60 \mathrm{~min}$ at $37^{\circ} \mathrm{C}$. At low $\mathrm{pH}(1.5-2.0)$, both enzyme preparations are rapidly inactivated; however, the large molecular weight species retains more activity at pH 2.0 (58\% after 10 min, $35 \%$ at $30 \mathrm{~min}$, and $14 \%$ after $60 \mathrm{~min}$ of preincubation) than the low molecular weight species (14\% of original activity after $30 \mathrm{~min}$ and only $5 \%$ after $60 \mathrm{~min}$ of preincubation at $\mathrm{pH}$ $2.0)$. The loss of activity at low $\mathrm{pH}$ is irreversible because raising the $\mathrm{pH}$ to 5.4 does not return enzyme activity to the level before

Table 1. Fat digestion in the stomach: comparison of in vivo lipolysis with in vitro hydrolysis of triglyceride by lingual lipase

\begin{tabular}{cccrcc}
\hline & & \multicolumn{4}{c}{ Products* of Lipolysis mol \% of total lipid } \\
\cline { 3 - 6 } Species & Study & TG & \multicolumn{1}{c}{ DG } & MG & FFA \\
\hline \multirow{2}{*}{ Human $\dagger$} & in vivo & 54.4 & 15.0 & 3.2 & 29.2 \\
& & \pm 4.2 & \pm 3.0 & \pm 0.4 & \pm 4.7 \\
& in vitro & 67.6 & 9.3 & 3.7 & 14.2 \\
& \pm 2.6 & \pm 1.1 & \pm 0.7 & \pm 2.9 \\
Ratł & in vivo & 77.3 & 16.4 & 2.3 & 7.3 \\
& & \pm 3.2 & \pm 2.8 & \pm 0.2 & \pm 1.2 \\
& in vitro & 77.7 & 9.2 & 2.8 & 10.3 \\
& & \pm 4.8 & \pm 2.4 & \pm 0.4 & \pm 2.0 \\
\hline
\end{tabular}

* TG, triglycerides; DG, diglycerides; MG, monoglycerides and FFA, free fatty acids.

$\dagger$ In vivo studies, the products of intragastric lipolysis were quantitated in gastric aspirates of eight infants (gestational age $28.9 \pm 0.4 \mathrm{wk}$, birth weight, $1010 \pm 67 \mathrm{~g}$; age at study, $6.0 \pm 0.8 \mathrm{wk}$ ) obtained $15 \mathrm{~min}$ after gavage feeding of an infant formula similar to the Enfamil premature formula but containing $91 \%$ long-chain triglyceride (Mead-Johnson Co.). In vitro assay of purified preparations of rat lingual lipase or of infant gastric aspirates was as described in "Materials and Methods." Data are mean \pm SEM.

$\$$ Adult rats were fed a mixture of milk and cream by stomach tube and the products of lipolysis were analyzed $30 \mathrm{~min}$ after feeding. 


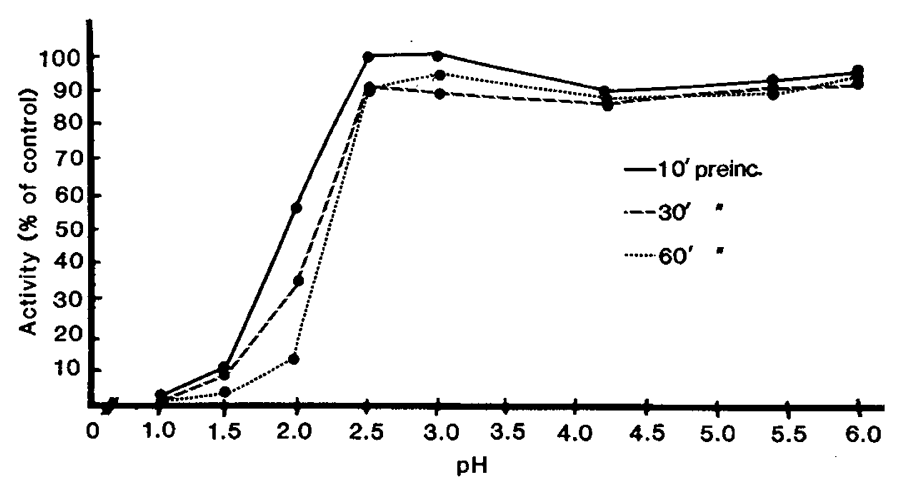

Fig. 1. Effect of preincubation at $\mathrm{pH} 1.0-6.0$ on the activity of high molecular weight ( $>500,000$ daltons) preparations of lingual lipase. $100,000 \mathrm{~g}$ supernatant preparations of rat lingual serous glands were preincubated for 10,30 , and $60 \mathrm{~min}$ at $37^{\circ} \mathrm{C}$ and $\mathrm{pH} 1.0-6.0$. After preincubation, lipase activity was measured in the assay system at $\mathrm{pH}$ 5.4 as described in the "Materials and Methods" section. Lipolytic activity is expressed as percentage of control activity. The enzyme in the control tubes was exposed to the entire range of $\mathrm{pH}$ levels while on ice for less than $1 \mathrm{~min}$; the $\mathrm{pH}$ was then immediately adjusted to 5.4 and lipolytic activity quantitated. Values are means of at least three experiments.

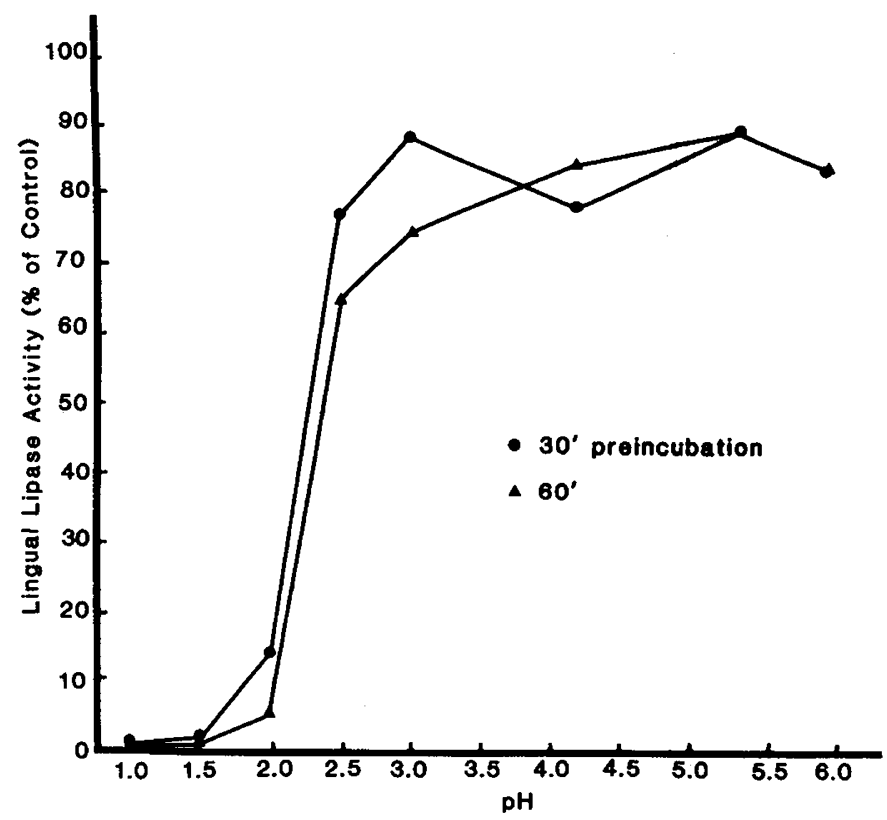

Fig. 2. Effect of preincubation at $\mathrm{pH} 1.0-6.0$ on the activity of low molecular weight $(46,000$ daltons) preparations of rat lingual lipase. Acetone-extracted preparations of rat lingual serous glands were incubated for 30 and $60 \mathrm{~min}$ at $37^{\circ} \mathrm{C}$ and $\mathrm{pH} 1.0-6.0$. Preincubation and assay conditions as described in Figure 1. Values are means of at least three experiments.

preincubation. Inactivation, in the $\mathrm{pH}$ range of 1.5-2.5, is shown in greater detail in Figure 3. In this experiment, we also investigated whether the nature of the preincubation buffer might affect the extent of enzyme inactivation. The large molecular weight enzyme is stable at $\mathrm{pH}$ above 2.4 during preincubation for 10 or $30 \mathrm{~min}$ at $37^{\circ} \mathrm{C}$. Below pH 2.4 , lipase activity is rapidly lost. There was a slight difference in the rate of inactivation during preincubation in the two buffers tested $\left(12.5 \mathrm{mM} \mathrm{Na}_{2} \mathrm{HPO}_{4}-\right.$ acetic acid buffer at pH 1.5-2.2 and glycine-HCl); slightly more enzyme activity was retained during preincubation in phosphateacetic acid buffer at pH 1.5-2.2 than in glycine- $\mathrm{HCl}$ buffer.

Effect of protein and lipids on the inactivation of lingual lipase at low $\mathrm{pH}$. In the series of experiments described below, we investigated whether proteins or lipids might prevent the loss of lipase activity at low $\mathrm{pH}$. Preincubation of rat lingual lipase at

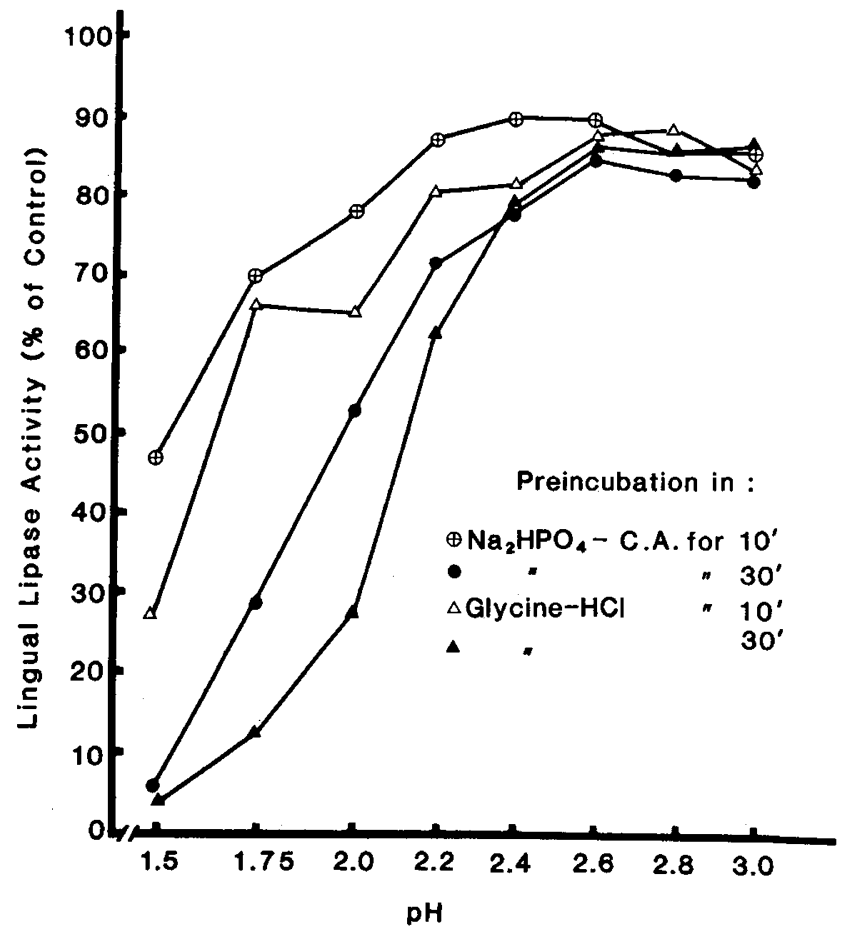

Fig. 3. Effect of preincubation at low pH, 1.5-3.0, on the activity of the high molecular weight species of rat lingual lipase. Preincubation was carried out in two separate buffers $\mathrm{Na}_{2} \mathrm{HPO}_{4}$-citric acid $(12.5 \mathrm{mM})$ or glycine- $\mathrm{HCl}(12.5 \mathrm{mM})$ for 10 and $30 \mathrm{~min}$ followed by assay of lipolytic activity at $\mathrm{pH}$ 5.4. Values are means of at least three experiments.

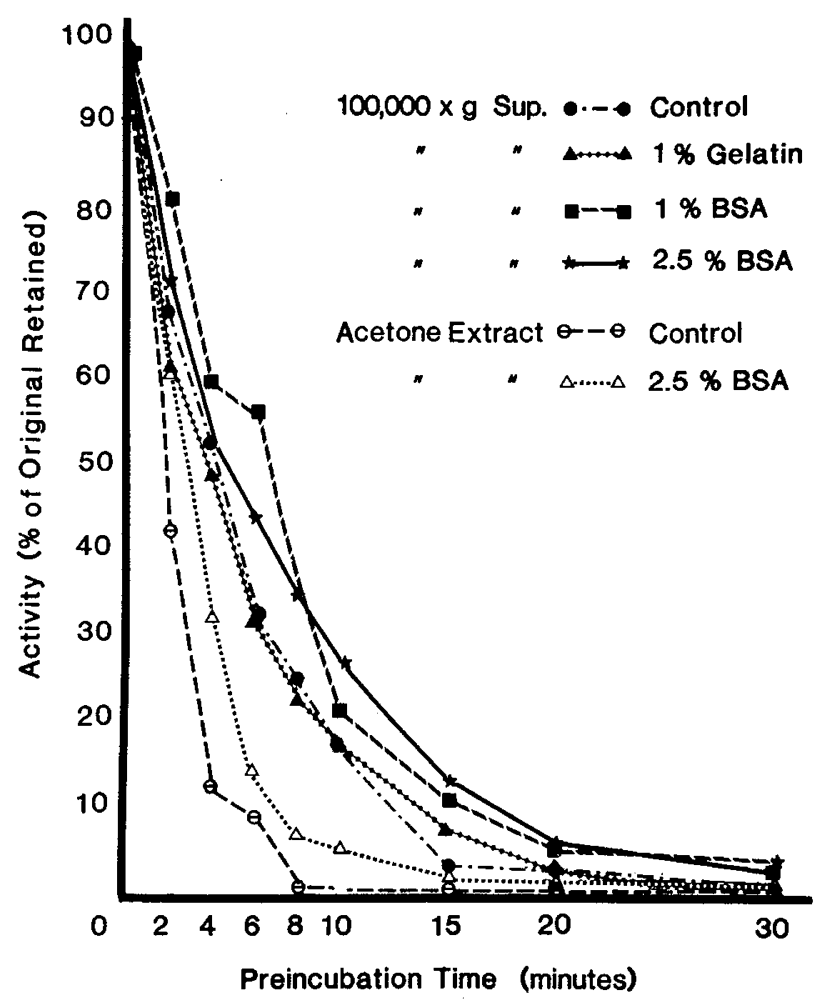

Fig. 4. Effect of protein-bovine serum albumin and gelatin on the inactivation of lingual lipase at low pH. Low molecular weight preparations (acetone-treated 100,000 $\mathrm{g}$ supernatant) of rat lingual lipase were preincubated at $37^{\circ} \mathrm{C}$ in glycine- $\mathrm{HCl}$ buffer $\mathrm{pH} 1.8$, alone (control) or in the presence of $2.5 \%$ bovine serum albumin for 0-30 min. High molecular weight rat lingual lipase $(100,000 \mathrm{~g}$ supernatant of rat lingual serous glands) was likewise preincubated alone (control) or in the presence of $1 \%$ gelatin or $1 \%$ and $2.5 \%$ bovine serum albumin for $0-30 \mathrm{~min}$. Lipolytic activity was then determined at pH 5.4. Values are means of at least three experiments. 
$\mathrm{pH} 1.8$ was performed with or without $1 \%$ gelatin and at 1 and $2.5 \%$ BSA. In addition to the large molecular weight species, we tested the effect of $2.5 \% \mathrm{BSA}$ on the low molecular weight species. The data (Fig. 4) show that proteins cannot prevent the inactivation of the two enzyme preparations at low $\mathrm{pH}$. All proteins tested maintained slightly higher activity during short preincubation only $(<10 \mathrm{~min})$. Although enzyme protection was slight, $2.5 \%$ albumin was the most effective in maintaining enzyme activity during the first few minutes of preincubation. Lipids, on the other hand, protected the enzyme very efficiently from inactivation at low $\mathrm{pH}$. We tested lecithin, a phospholipid that is not hydrolyzed by lingual lipase (Fig. 5) and triolein, the substrate of the enzyme (Fig. 6). Triolein seems to be more efficient in preventing the loss of activity than lecithin. Lecithin at a concentration of $50 \mathrm{mM}$ preserves $60 \%$ of lipase activity after $30 \mathrm{~min}$ of preincubation at $\mathrm{pH} 2.0$. Protection decreases at lower lecithin concentrations, $35 \%$ at $25 \mathrm{mM}$ and only $2-3 \%$ at $5-10 \mathrm{mM}$. When lingual lipase is preincubated at $\mathrm{pH} 2.0$ with $10 \mathrm{mM}$ triolein, $94 \%$ of the original activity is preserved after 15 min and $66 \%$ after 30 min of preincubation.

Effect of pepsin on lipase activity. Because pepsin is active at low $\mathrm{pH}$, considerable proteolytic activity is present in the stomach between meals. We have tested the effect of pepsin (porcine, Sigma Chemical Comp, St. Louis, MO, EC 3.4.2.3.1) on lingual lipase during preincubation at $\mathrm{pH} 2.0$ for $30 \mathrm{~min}$. At low pepsin concentrations $(25 \mathrm{U} / \mathrm{ml})$, lingual lipase activity decreases at rates similar to that of the controls; however, high pepsin concentrations $(18,750 \mathrm{U} / \mathrm{ml})$ protect the lipase from inactivation (Fig. 7). Because pepsin at the high concentration amounts to 22 $\mathrm{mg} / \mathrm{ml}$ of enzyme protein, we assume that its protection is similar to that of serum albumin. The pepsin preparations were tested for proteolytic activity (35) and found to be fully active. It is possible that the hydrophobic nature of lingual lipase $(49,54)$ prevents its denaturation by pepsin.

Effect of low $p H$ on the lipase in gastric aspirates of newborn infants. Because of the similarity in enzyme characteristics, we compared the stability to low $\mathrm{pH}$ of the lipase in four specimens of gastric aspirates obtained at birth, with the stability of rat

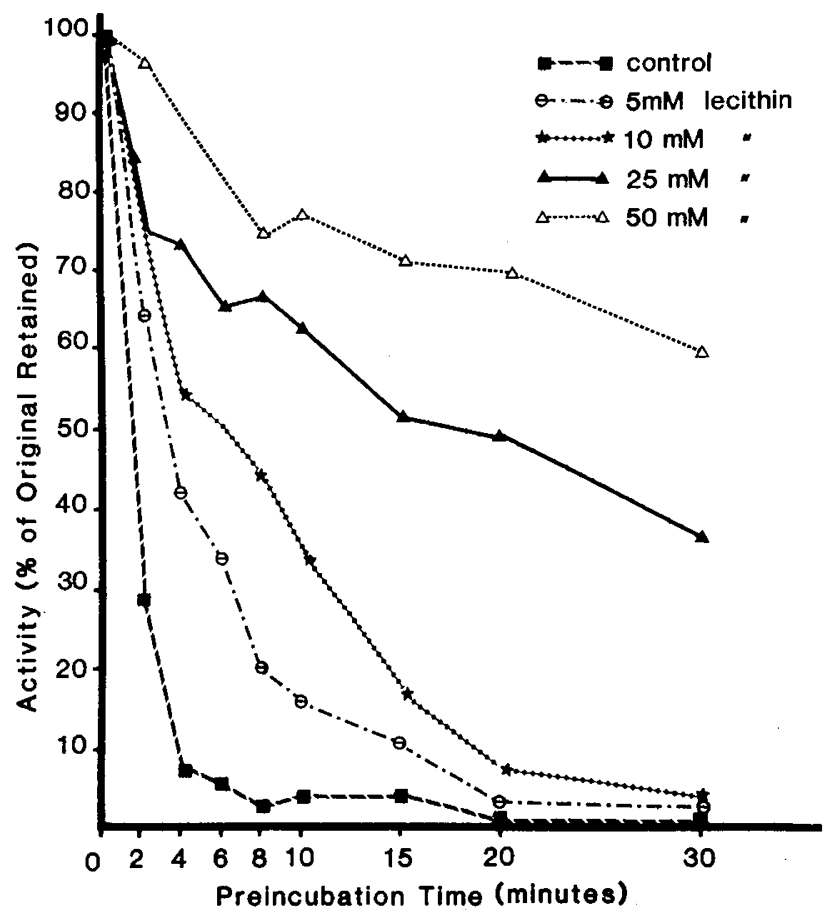

Fig. 5. Effect of lecithin on the inactivation of rat lingual lipase at low $\mathrm{pH}$. Low molecular weight preparations of rat lingual lipase were preincubated alone (control) at $37^{\circ} \mathrm{C}$ in glycine- $\mathrm{HCl}$ buffer, $\mathrm{pH} 2.0$ or in the presence of various concentrations of lecithin. Lipolytic activity was determined, after preincubation, at $\mathrm{pH}$ 5.4. Values are means of at least three experiments.

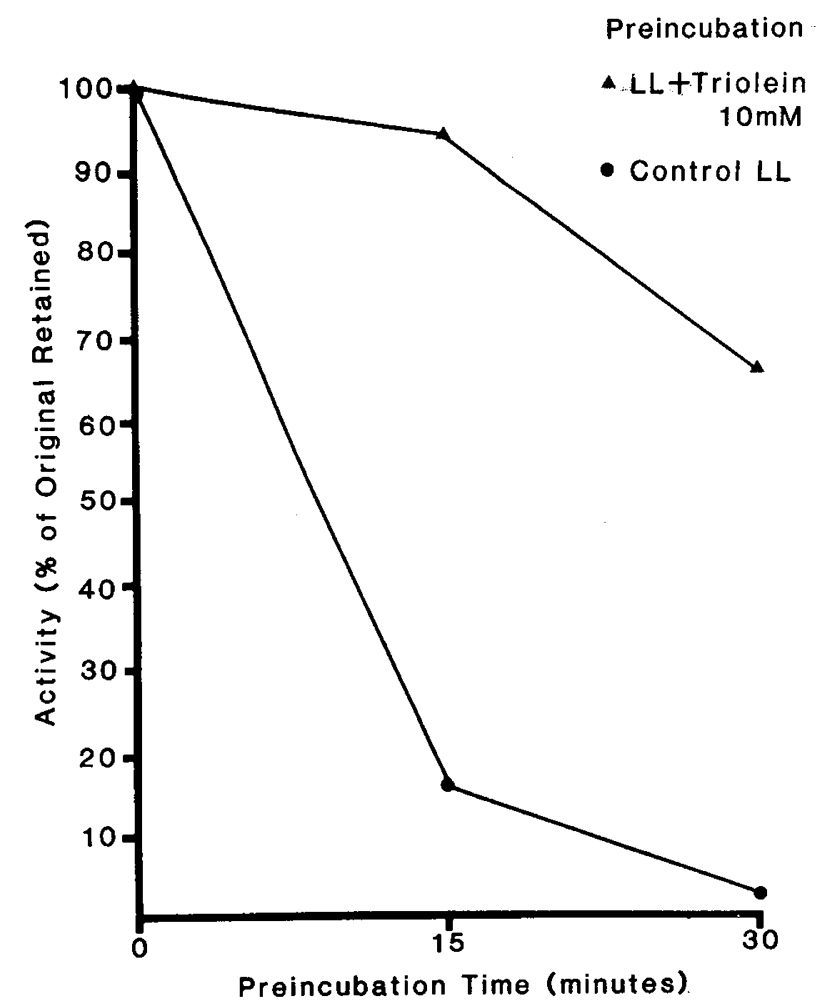

Fig. 6. Effect of triolein on the inactivation of rat lingual lipase at low $\mathrm{pH}$. Low molecular weight preparations of rat lingual lipase were preincubated alone (control) at $37^{\circ} \mathrm{C}$ in glycine- $\mathrm{HCl}$ buffer $\mathrm{pH} 2.0$, or in the presence of $10 \mathrm{mM}$ triolein. Lipolytic activity was determined, after preincubation, at $\mathrm{pH}$ 5.4. Values are means of at least three experiments.

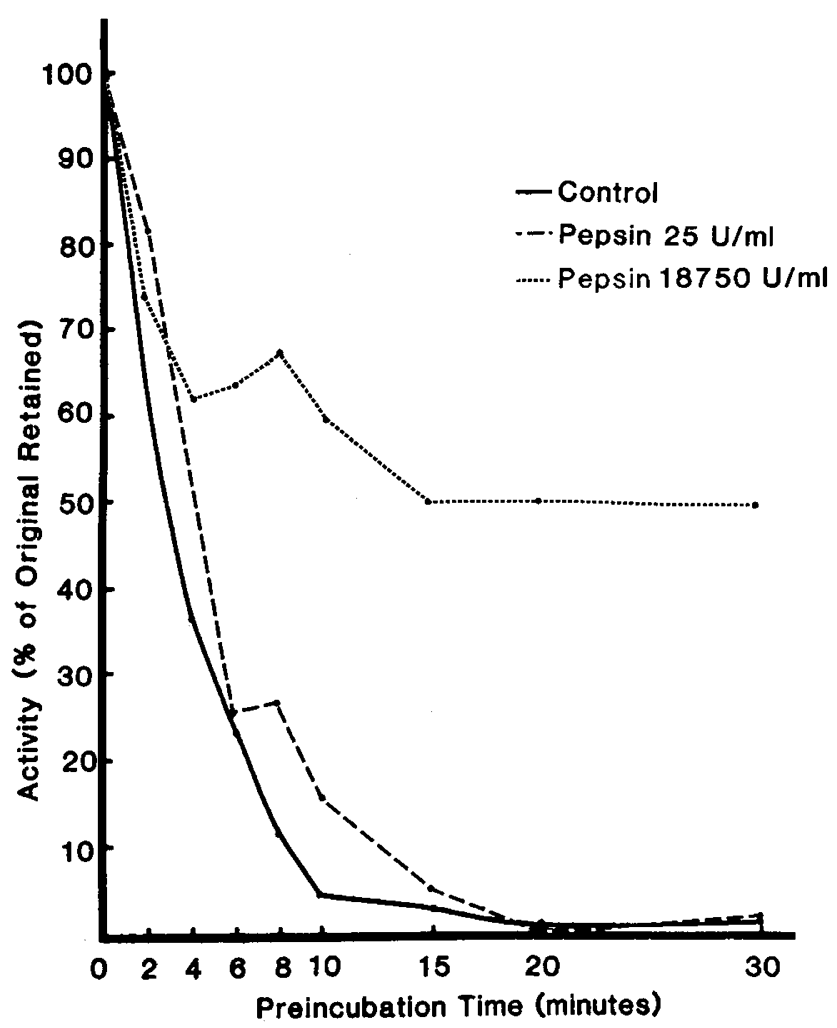

Fig. 7. Effect of pepsin on the activity of lingual lipase. Low molecular weight preparations of lingual lipase were preincubated alone (control), or in the presence of various concentrations of pepsin, in glycine- $\mathrm{HCl}$ buffer, $\mathrm{pH}$ 2.0. Lipolytic activity was determined at $\mathrm{pH}$ 5.4. Values are means of at least three experiments. 


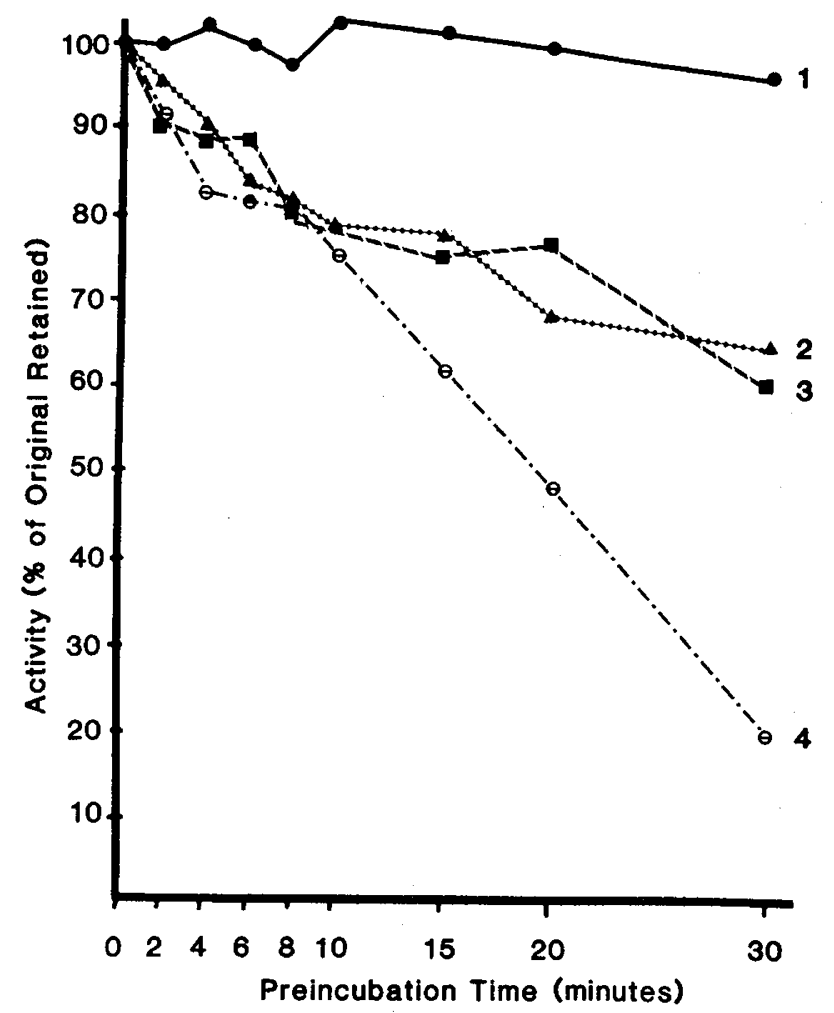

Fig. 8. Effect of low pH on the lipolytic activity in gastric aspirates of newborn infants. Gastric aspirates obtained at birth from term infants were preincubated at $\mathrm{pH} 1.6$ (glycine- $\mathrm{HCl}$ buffer) followed by quantitation of lipase activity at $\mathrm{pH} 5.4$.

lingual lipase described above. As can be seen, in Figure 8 , there is marked variation in the loss of activity during preincubation at $\mathrm{pH} 1.6$ for $30 \mathrm{~min}$. Whereas the lipase activity in one specimen was stable during the entire 30 -min period, two specimens lost about 35 and $40 \%$ of their original lipase activity and the fourth specimen retained less than $20 \%$ of its original activity after 30 min of preincubation at low $\mathrm{pH}$. In view of our findings that rat lingual lipase is protected from inactivation by lipids and to a lesser extent by protein, we have quantitated the amount of lipid and protein in the gastric aspirates, but found no marked differences among the four specimens. There might, therefore, be additional components in the gastric aspirates of newborn infants that protect the lipase from inactivation at low $\mathrm{pH}$.

\section{DISCUSSION}

The digestion and absorption of dietary fat is the process of transport of water insoluble molecules from one water phase, the intestinal lumen, to another water phase, the lymph and plasma. During this process, triglycerides (the major component of dietary fat) are first hydrolyzed, followed by dispersion of the products of lipolysis into absorbable forms. Whereas the major part of lipid absorption occurs in the intestine-with the exception of short and medium chain fatty acids, which can be absorbed directly through the gastric mucosa $(4,30)$-hydrolysis of triglyceride starts in the stomach $(7,8,28-30,40,42,51,58$, 66). Intragastric lipolysis is necessary for normal digestion and absorption of dietary fat. Recent animal studies have shown that after diversion of oral secretions from the stomach, there is a marked fall not only in fat hydrolysis in the stomach but also in the duodenum, jejunum, and ileum (51). Concomitantly, there is a marked increase in the excretion of fat and bile salts (57). Fat digestion in the stomach becomes a much more important process in conditions of physiologic and pathologic pancreatic insufficiency. At birth, the levels of pancreatic lipase $(9,37,47$, $69)$ and bile salts $(47,68)$ are low, indicating that the major components of intestinal fat digestion are not sufficiently developed for the normal digestion of fat, the major energy source of the newborn (20).

Newborn infants, even very premature ones, absorb $85-95 \%$ of dietary fat $(3,48,60)$, suggesting that fat digestion proceeds by mechanisms different from those in the adult. Likewise, in cystic fibrosis, a genetic disease resulting in severe pancreatic insufficiency (50), as much as $50-80 \%$ of dietary fat is absorbed in the absence of pancreatic lipase (38). Recent studies show that lingual lipase is well developed at birth [as early as $26 \mathrm{wk}$ gestation (27)] and that it remains fully active in persons with cystic fibrosis $(1,56)$. Furthermore, because of low bicarbonate secretion in pancreatic insufficiency $(14,19)$, the upper small intestine maintains a low basal and postprandial pH $(1,13)$, compatible with the activity of lingual lipase. Although under normal conditions, the stomach is its major site of activity, lingual lipase probably continues to digest fat in the intestine of the newborn as well as in other cases of pancreatic insufficiency. Studies that compare the characteristics of lingual lipase with those of pancreatic lipase suggest that the former is a much less complex enzyme $(21,23$, 33 ) and might, therefore, be better suited for the conditions in the immature gastrointestinal tract. Present evidence suggests that lingual lipase is secreted continuously from the serous glands and therefore that it might accumulate in the stomach between meals $(1,27,28)$. The enzyme secreted during or immediately after feeding reaches the stomach when the $\mathrm{pH}$ is in the range of 4.0-6.0. The enzyme that reaches the stomach $2-3 \mathrm{hr}$ postprandially is exposed to low $\mathrm{pH}$ and might therefore be inactivated by the acidity and peptic activity (64) in the stomach. The present study was, therefore, designed to assess the stability of lingual lipase in the gastric environment. We have shown previously that during the purification of lingual lipase one obtains a high molecular weight species, which seems to be an aggregate of enzyme with cell membrane lipids, and a low molecular weight species, which is probably the form in which the enzyme is secreted because it has an identical molecular weight $(44-48,000)$ as that of the lipase in human gastric aspirates $(8,27,65)$. Although these two forms hydrolyze triglyceride at similar rates, we had no previous information on their stability to low $\mathrm{pH}$. Our present study shows that both forms of enzyme are stable at $\mathrm{pH}>2.5$ and that at low $\mathrm{pH}$ there is irreversible loss of activity (Figs. 1-3). The high molecular weight form is however slightly more resistant to low $\mathrm{pH}$, suggesting that lipids might protect the enzyme. Indeed, as seen in Figs. 5 and 6 , loss of activity is reduced markedly when lipids are present during preincubation of the low molecular form of lingual lipase at low $\mathrm{pH}$. The substrate of the enzyme, triolein, protects the enzyme at lower concentrations $(10 \mathrm{mM})$ than lecithin $(25-50 \mathrm{mM})$, a lipid that is not hydrolyzed by the enzyme (41). Proteins, on the other hand, have only little protective action (Fig. 4). Lingual lipase does not seem susceptible to peptic denaturation (Fig. 7); thus, at low concentrations [similar to pepsin levels in the stomach of newborn infants (2)], loss of enzyme activity is not greater than during incubation at low $\mathrm{pH}$ in the absence of pepsin. Very high pepsin concentrations, sufficient to raise the protein concentration in the incubation system to $2.2 \%$ seem to protect the enzyme from inactivation at low $\mathrm{pH}$. The protective action of pepsin is much higher than that of similar concentrations of gelatin or albumin, and might be related to the properties of the enzyme (pepsin) protein. Although we do not know what prevents the peptic digestion of lingual lipase, it is possible that because it is a highly hydrophobic protein (54), it is much more resistant to proteolysis than pancreatic lipase.

Conditions in the stomach of the newborn may further stabilize lingual lipase (Fig. 8). We do not yet know why the lipase in some gastric aspirates is stable at $\mathrm{pH} 1.6$, whereas in others there is a variable loss of activity. The data in this study suggest that in the breast-fed infant, lingual lipase might remain fully active in the stomach between meals because gastric $\mathrm{pH}$ rarely falls below 3.5 (44). Salivary amylase, another digestive enzyme of oral origin, is able to pass through the stomach and retain 
sufficient activity to provide $15-40 \%$ of total duodenal amylase activity in man (61).

Because of the relatively high $\mathrm{pH}$ in the stomach of breast-fed infants, the digestive enzymes in human milk, alpha-amylase $(31,34)$ and bile salt-stimulated lipase $(16,17,45)$ retain sufficient activity to hydrolyze carbohydrates and fats in the duodenum.

Enzymes of extrapancreatic origin provide alternate mechanisms for nutrient digestion in the newborn $(18,22,37)$. These mechanisms differ from those in the adult, but seem equally efficient for the digestion and absorption of food. There might indeed be advantages in the slow development of pancreatic function that could be important for the structural and functional development of the intestine. The "wear and tear" by pancreatic proteolytic enzymes would be less disruptive to the immature intestinal mucosa, and probably is one of the reasons for lower turnover of intestinal epithelial cells in the newborn $(18,22)$. Furthermore, intestinal brush-border enzymes, important in neonatal digestion (39), would not be degraded as rapidly at low levels of pancreatic enzymes (36).

\section{REFERENCES AND NOTES}

1. Abrams, C. K., Hamosh, M., Hubbard, V. S., Dutta, S. K., and Hamosh, P.: Lingual lipase in cystic fibrosis.: quantitation of enzyme activity in the upper small intestine in patients with pancreatic insufficiency. J. Clin. Invest., 73: (1984).

2. Agunod, M., Yamaguchi, N., Lopez, R., Luhby, A. H., and Glass, G. B. J.: Correlative study of hydrochloric acid, pepsin, and intrinsic factor secretion in newborns and infants. Am. J. Dig. Dis., 14: 400 (1969).

3. Alemi, B., Hamosh, M., Scanlon, J. W., Salzman-Mann, C., and Hamosh, P. Fat digestion in very low birth weight infants: effect of addition of human milk to low birth weight formula. Pediatrics, 68: 484 (1981).

4. Aw, T. Y. and Grigor, M. R.: Digestion and absorption of milk triacylglycerols in 14 day old suckling rats. J. Nutr., 110: 2133 (1980).

5. Belfrage, P. and Vaughan, M.: Simple liquid-liquid partition system for isolation of labeled oleic acid from mixtures of glycerides. J. Lipid Res., 10:341 (1969).

6. Borgstrom, B.: The importance of phospholipids, pancreatic phospholipase A 2 , fatty acids and other factors for the digestion of dietary fat: in vitro experiments with porcine enzymes. Gastroenterology, 78: 954 (1980).

7. Borgstrom, B., Dahlquist, A., Lundh, G., and Sjovall, J.: Studies of intestinal digestion and absorption in the human. J. Clin. Invest., 36: 1521 (1957)

8. Cohen, M., Morgan, G. R. H., and Hofmann, A. F.: Lipolytic activity of human gastric and duodenal juice against medium and long-chain triglycerides. Gastroenterology, 60: 1 (1971).

9. Delachaume-Salem, E. and Sarles, H.: Evolution en function de l'age de la secretion pancreatique humaine normale. Biol. Gastroenterol. (Paris), 2: 135 (1970).

10. Deschodt-Lanckman, M., Robberecht, P., Camus, J., Baya, C., and Christophe, $\mathrm{J} .:$ Hormonal and dietary adaption of rat pancreatic hydrolases before and after weaning. Am. J. Physiol., 226: 39 (1974)

11. Dole, V. P. and Meinertz, H.: Microdetermination of long-chain fatty acids in plasma and tissues. J. Biol. Chem., 235: 2595 (1960)

12. Dutta, S. K., Hamosh, M., Abrams, C. K., Hamosh, P., and Hubbard, V. S. Quantitative estimation of lingual lipase activity in the upper small intestine in adult patients with pancreatic insufficiency. Gastroenterology, 82: 1047 (1982).

13. Dutta, S. K., Russell, R. M., and Iber, F. L.: Influence of exocrine pancreatic insufficiency on the intraluminal $\mathrm{pH}$ of the proximal small intestine. Am. J. Dig. Dis., 24: 529. (1979).

14. Dutta, S. K., Russell, R. M., and Iber, F. L.: Imparied acid neutralization in the duodenum in pancreatic insufficiency. Dig. Dis. Sci., 24: 775 (1979).

15. Folch, J., Lees, M., and Sloane-Stanley, G. H.: Simple method for the isolation and purification of total lipids from animal tissues. J. Biol. Chem., 226: 497 (1957).

16. Fredrikzon, B., Hernell, O., Blackberg, L., and Olivecrona, T.: Bile salt stimulated lipase in human milk: Evidence of activity in vivo and of a role in the digestion of milk retinol esters. Pediatr. Res., 12: 1048 (1978).

17. Freudenberg, E.: Die Frauenmilch-Lipase. (S. Karger, A. G., Basel, 1953).

18. Grand, R. J., Watkins, J. B., and Torti, F. M.: Development of the human gastrointestinal tract. A Review. Gastroenterology, 70: 790 (1978).

19. Hadorn, B., Zoppi, G., Shmerling, D. H., Prader, A., McIntyre, I., and Anderson, C. M.: Quantitative assessment of exocrine pancreatic function in infants and children. J. Pediatr., 73: 39 (1968).

20. Hambraeus, L.: Proprietary milk versus human breast milk in infant feeding Pediatr. Clin. N. Am., 24: 17 (1977).

21. Hamosh, M.: Lingual and breast milk lipases. In: L. A. Barness: Advances in Pediatrics, Vol 29. pp 33. (Year Book Medical Publisher, Chicago, 1982).

22. Hamosh, M.: The development of the metabolic and transport functions of the gastrointestinal system. In: C. T. Jones: Biochemical Development of the Fetus and Neonate pp. 591. (Elsevier Biomedical Press, Amsterdam, 1982).

23. Hamosh, M.: Lingual Lipase. In: B. Borgstrom and H. L. Brockman: Lipolytic
Enzymes (Elsevier, Amsterdam, 1983).

24. Hamosh, M. and Burns, W. A.: Lipolytic activity of human lingual glands (Ebner). Lab. Invest., 37: 603 (1977)

25. Hamosh, M., Ganot, D., and Hamosh, P.: Rat lingual lipase: characteristics of enzyme activity. J. Biol. Chem., 254: 12121 (1979).

26. Hamosh, M., Klaeveman, H. L., Wolf, R. O., and Scow, R. O.: Pharyngeal lipase and digestion of dietary triglyceride in man. J. Clin. Invest., 55: 908 (1975).

27. Hamosh, M., Scanlon, J. W., Ganot, D., Likel, M., Scanlon, K. B., and Hamosh, P.: Fat digestion in the newborn: characterization of lipase in gastric aspirates of premature and term infants. J. Clin. Invest., 67: 838. (1981).

28. Hamosh, M. and Scow, R. O.: Lingual lipase and its role in the digestion of dietary fat. J. Clin. Invest., 52: 88. (1973).

29. Hamosh, M. Sivasubramanian, K. N., Saltzman-Mann, C., and Hamosh, P.: Fat digestion in the stomach of premature infants. I. Characteristics of lipase activity. J. Pediatr., 93: 674 (1978).

30. Helander, H. F. and Olivecrona, T.: Lipolysis and lipid absorption in the stomach of the suckling rat. Gastroenterology, 59: 22 (1970).

31. Heitlinger, L. A., Lee, P. C., and Lebenthal, E.: Mammary amylase: a possible alternate pathway of carbohydrate digestion in infancy. Pediatr. Res., 17: 15 (1983).

32. James, A. H.: The Physiology of Gastric Digestion. p. 25 (E. Arnold Publishers, Ltd., London 1957).

33. Jensen, R G. Clark, R. M. DeJong, F. A., Hamosh, M., Liao, T. H., and Mehta, R. N.: The lipolytic triad: human lingual, breast milk and pancreatic lipases: physiological implications of their characteristics in digestion of dietary fat. J. Pediatr. Gastroenterol. Nutr., 1: 243 (1982).

34. Jones, J. B., Mehta, N. R., and Hamosh, M.: Alpha-amylase in preterm human milk. J. Pediatr. Gastroenterol. Nutr., 1: 43 (1982).

35. Kasbekar, D. K. and Blumenthal, G. H. Frog gastric tubular cells: isolation, culture and some practices. Gastroenterology, 73: 881. (1977)

36. Kediger, M., Hauri, H. P., and Haffen, K.: Turnover studies of human intestinal brush border membrane glycoproteins in organ culture. Enzyme, 24: 26 (1979)

37. Koldovsky, O.: Development of function of the small intestine in mammals and man. (Karger, Basel, 1969).

38. Lapey, A., Kattwinkel, J., di Sant'Agnese, P. A., and Laster, L.: Steatorrhea and azotorrhea and their relation to growth and nutrition in adolescents and young adults with cystic fibrosis. J. Pediatr., 84: 328. (1974).

39. Lebenthal, E. and Lee, P. C.: Glycoamylase and disaccaridase activities in normal subjects and in patients with mucosal injury of the small intestine. J. Pediatr. 97: 389 (1980)

40. Liao, T. H., Buczek, R. J., Mehta, N. R., Grylack, L. J., Hamosh, P., and Hamosh, M.: Fat digestion in the stomach: hydrolysis of formula triglyceride by premature infants. Clin. Res., 31:285a 1983.

41. Liao, $\Upsilon$. H., Hamosh, M., and Hamosh, P.: Fat digestion in the stomach: Mechanism of action and substrate specificity of lingual lipase. Fed. Proc., 40: 941 (1981)

42. Liao, T. H. Hamosh, M., and Hamosh P.: Development of preduodenal fat digestion in the rat. Fed. Proc., 41: 103 (1982).

43. Lowry, O. H., Rosebrough, N. J., Farr, J. L., and Randall, R.H.: Protein measurement with the folin phenol reagent. J. Biol. Chem., 193: 265 (1951).

44. Mason, S.: Some aspects of gastric function in the newborn. Arch. Dis. Child., 37: 387 (1962).

45. Mehta, N. R. Jones, J. B., and Hamosh, M. Lipases in human milk: ontogeny and physiologic significance. J. Pediatr. Gastroenterol. Nutr., 1: 317 (1982).

46. Muller, D. P. R., McCollum, J. P. K., Trompeter, R. S., and Harries, J. T. Studies on the mechanism of fat absorption in congenital isolated lipase deficiency. Gut, 16: 838 (1975)

47. Norman, A., Strandvik, B., and Ojamae, O.: Bile acids and pancreatic enzymes during absorption in the newborn. Acta Pediatr. Scand., 61: 571 (1972).

48. Okamoto, E., Muttart, C. M., Zucker, C. L., and Heird, W. C.: Use of mediumchain triglycerides in feeding the low birth weight infant. Am. J. Dis. Child., 136: 428 (1982).

49. Patton, J. S., Rigler, M. W., Liao, T. H., Hamosh, P., and Hamosh, M.: Hydrolysis of triacylglycerol emulsions by lingual lipase-a microscopic study. Biochim. Biophys. Acta, 712: 400 (1982).

50. Park, R. W. and Grand, R. J.: Gastrointestinal manifestations of cystic fibrosis: a review. Gastroenterology, $81: 1143$ (1981).

51. Plucinski, T. M., Hamosh, M., and Hamosh, P.: Fat digestion in rat: Role of lingual lipase. Am. J. Physiol., 237: E54l (1979).

52. Rapport, M. M. and Alonzo, N.: Photometric determination of fatty acid ester groups in phospholipids. J. Biol. Chem., 217: 193 (1958).

53. Rey, J., Frezal, F., Royer, P., and Lamy, M.: L'absence congenitale de lipase pancreatique. Arch. Fr. Pediatr., 23: 5 (1966).

54. Roberts, I. M., Montgomery, R. K., and Carey, M. C.: Linqual lipase hydrolyzes triglycerides in the presence of lecithin and bile salt micelles. Gastroenterology, 82: 1163 (1982).

55. Ross, C. A. C. and Sammons, H. C.: Non pancreatic lipase in children with pancreatic fibrosis. Arch. Dis. Child., 30: 428 (1955).

56. Roulet, M., Weber, A. M., Paradys, Y., Roy, C. C., Chartrand, L., LaSalle, R and Morin, C. L.: Gastric emptying and lingual lipase activity in cystic fibrosis. Pediatr. Res., 14: 1387 (1980).

57. Roy, C. C., Roulet, M., Lefebre, D., Chartrand, L., Lepage, C., and Fournier, L. A.: The role of gastric lipolysis in fat absorption and bile acid metabolism in the rat. Lipids, 14:811 (1979).

58. Schonheyder, F. and Volqvartz, K: The gastric lipase in man. Acta Physiol. Scand., 11: 349 (1946). 
59. Sheldon, W.: Congenital pancreatic lipase deficiency. Arch. Dis. Child., 39: 268 (1964).

60. Shenai, P. J., Reynolds, J. W., and Babson, S. G.: Nutritional balance studies in very low birth weight infants: Enhanced nutrient retention rates by an experimental formula. Pediatrics, 66: 233 (1980).

61. Skude, G. and Ihse, I.: Salivary amylase in duodenal aspirates. Scand. J. Gastroenterol., VII: 17 (1976).

62. Small, D. M.: A classification of biologic lipids based upon their interaction in aqueous systems. J. Am. Oil Chem. Soc., 45: 108. (1968).

63. Staggers, J. E., Fernando-WarnaKulasuriya, G. J. P., and Wells, M. A.: Studies on fat digestion, absorption and transport in the suckling rat. II. Triacylglycerols: molecular species, stereospecific analysis and specificity of hydrolysis by lingual lipase. J. Lipid Res., 22: 675 (1981).

64. Taylor, W. H.: Studies on gastric proteolysis. Biochem. J., 71: 73 (1959).

65. Tiruppathi, C. and Balasubramanian, K. A.: Purification and properties of an acid lipase from human gastric juice. Biochim. Biophys. Acta, 712: 692 (1982)

66. Volhard, F.: Über das fettspaltende Ferment des Magens. Z. Clin. Med., 42: 414 (1901).
67. von Ebner, V.: Cited in v. Koelliker's Handb. d. Geweb-lehre d. Menscheu. Vol. 3 p. 18.: Die acinosen Drusen der Zunge und ihrre Beziehungen zu den Geschmacks-Organen-(Leuschner and Lubensky, Graz, Austria, 1899).

68. Watkins, J. B., Szczpanik, P., Ingall, D., Klein, D. P., and Lester, R.: Bile salt metabolism in the newborn infant. Measurement of pool size and synthesis by stable isotopic techniques. N. Engl. J. Med., 288: 431 (1973)

69. Zoppi, G., Andreotti, G., Pajno-Ferrara, F., Njai, D. M., and Gaburro, D.: Exocrine pancreatic function in premature and full-term neonates. Pediatr. Res., 6: 880 (1972)

70. This study was supported by National Institutes of Health Grants AM-26641 and HD-10823, and by a grant from the Mead Johnson Company. We thank Dr. J. W. Scanlon and Mrs. K. B. Scanlon for the supply of gastric aspirates from newborn infants, and Ms. Marguerite Starry for secretarial help.

71. Requests for reprints should be addressed to: Dr. Margit Hamosh' Department of Pediatrics, Georgetown University Medical Center, 3800 Reservoir Road N.W., Washington, DC 20007.

72. Received for publication March 8, 1983

73. Accepted for publication June 20, 1983.

\title{
Longitudinal Studies on Metabolic Rate, Heat Loss, and Energy Cost of Growth in Low Birth Weight Infants
}

\author{
P. J. J. SAUER, ${ }^{(34)}$ H. J. DANE, AND H. K. A. VISSER \\ Department of Pediatrics, Erasmus University and Academic Hospital Rotterdam/Sophia Children's Hospital \\ Department of Applied Physics, Delft University of Technology, Delft, The Netherlands
}

\section{Summary}

Longitudinal studies on total and resting metabolic rate and total heat loss were made in 14 LBW infants, age 1-58 d. Metabolic rate was calculated from indirect calorimetry, heat loss was measured by direct calorimetry. Total metabolic rate and total heat loss were lowest during the first week of life, 178.9 \pm 18.0 and $171.8 \pm 15.5 \mathrm{~kJ} \cdot \mathrm{kg}^{-1} \cdot 24 \mathrm{~h}^{-1}$, respectively. During the age period of 8-58 d both total metabolic rate and heat loss showed a very slight increase with age: mean total metabolic rate was $278.8 \pm 2.6$ and mean total heat loss $257.0 \pm 3.4 \mathrm{~kJ} \cdot \mathrm{kg}^{-1}$. $24 \mathrm{~h}^{-1}$. Resting metabolic rate was $171.0 \pm 25.2 \mathrm{~kJ} \cdot \mathrm{kg}^{-1} \cdot 24 \mathrm{~h}^{-1}$ during the first week of life and $248.0 \pm 2.5$ during $\mathrm{d}$ 8-58.

The energy cost of components of new tissue was calculated from the energy balance equation. $\mathbf{E}_{\text {components }}$ during the second week of life was $25.5 \pm 4.9 \mathrm{~kJ} / \mathrm{g}$ weight gain and $11.9 \pm 0.4 \mathrm{~kJ} /$ $\mathrm{g}$ weight gain over subsequent weeks. The net energy cost of tissue synthesis, calculated from the difference between indirect and direct calorimetry was $3.2 \pm 1.1 \mathrm{~kJ} / \mathrm{g}$ weight gain during the second week and $1.1 \pm 0.1 \mathrm{~kJ} / \mathrm{g}$ weight gain in the following weeks. A neonate who receives a caloric intake of $535 \mathrm{~kJ} \cdot \mathrm{kg}^{-1}$. $24 \mathrm{~h}^{-1}$ and is growing at a rate of $17 \mathrm{~g} \cdot \mathrm{kg}^{-1} \cdot 24 \mathrm{~h}^{-1}$ will use $42 \%$ of the caloric intake for maintenance and thermoregulation, $6 \%$ for activity, $38 \%$ for the components of new tissue, $\mathbf{4} \%$ for tissue synthesis and $10 \%$ for loss in faeces and urine.

\section{Abbreviations}

BWT, birth weight

GA, gestational age

LBW, low birth weight

VLBW, very low birth weight
The prognosis for survival of VLBW infants is improving (30). The quality of outcome will depend on adequate growth and caloric intake during the critical postnatal period of development as well as on adequate circulatory and ventilatory support. Studies concerning caloric intake and growth in VLBW infants are therefore necessary. The energy balance equation makes it possible to calculate the energy cost of growth and to give guidelines for the caloric intake of these infants $(6,8,11,20,24)$.

The energy balance equation has been defined as $(24,27)$ :

$$
\text { Energy }_{\text {intake }}=\text { Energy }_{\text {excreted }}+\text { Energy }_{\text {expended }}+\text { Energy }_{\text {components }}
$$

Energy $_{\text {intake }}$ represents the energy in the food. Energy excreted $_{\text {Occurs }}$ mainly via the faeces in the postnatal period. Energy ${ }_{\text {expended }}$ includes 1) the energy used in maintenance, 2) the energy used for thermoregulation, 3) the energy used in activity, and 4) the energy used for the synthesis of new tissue. Energy expended $_{\text {is equal }}$ to the metabolic rate and can be measured by indirect calori-

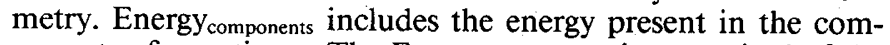

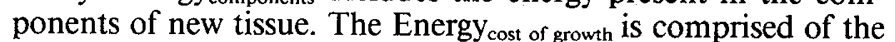
energy required for the synthesis of new tissue and the energy stored in the components of this new tissue:

$$
\text { Energy }_{\text {cost of growth }}=\text { Energy }_{\text {components }}+\text { Energy }_{\text {synthesis }} \text {. }
$$

The cost of tissue synthesis represents energy required for the organisation of the components of new tissue $(6,9,27,29)$ and for the formation of complex proteins, lipids, carbohydrates, and combinations thereof $(14,15)$. All energy used for maintenance, thermoregulation, and activity is given off as heat. Part of the energy consumed for tissue synthesis is converted to heat and given off. Another part of the energy for tissue synthesis is not 